\title{
The Fintech Revolution: An Opportunity for the West African Financial Sector
}

\author{
Hua Wilfried Serge Koffi \\ School of Economics, Shanghai University, Shanghai, China \\ Email: khwilfried@yahoo.fr
}

How to cite this paper: Koffi, H.W.S. (2016) The Fintech Revolution: An Opportunity for the West African Financial Sector. Open Journal of Applied Sciences, 6, 771782.

http://dx.doi.org/10.4236/ojapps.2016.611068

Received: September 23, 2016

Accepted: October 15, 2016

Published: October 18, 2016

Copyright (@) 2016 by author and Scientific Research Publishing Inc. This work is licensed under the Creative Commons Attribution International License (CC BY 4.0).

http://creativecommons.org/licenses/by/4.0/

(c) (i) Open Access

\begin{abstract}
Fintech provides alternative solutions and business models that could render traditional banking processes obsolete. This paper assesses the opportunity that could be taken to West Africa by using Fintech's financial system. It describes the current West African financial sector, the way of digitization settlement, and lastly, the financial market segments of Fintech. Financial sector creates a massive amount of data exploiting by Fintech companies that are using to segment customer populations, identify opportunities for new products and services and optimize pricing. In this segment, products may use data and analytics to computerize the decisionmaking processes. Innovative start-ups, retailers, established banks, card companies and other payment services providers are the Payment systems that underpin the services that enable funds to be transferred between people and institutions. For the financial system (banking), Fintech offers sustainable and realistic opportunities by enhancing the value proposition and driving sales, reducing operating costs, making easy access to loans, and lowering interest rates. After showing the advantages of using Fintech services, the findings are that Fintech could improve both financial services and access to services in the West African economy.
\end{abstract}

\section{Keywords}

Banking, Fintech Revolution, Financial Services, West Africa Economy Monetary Union (WAEMU)

\section{Introduction}

The 2008 financial crisis has generated a confidence loss among financial institutions (banks), businesses, and customers. This erosion of trust is getting worse over time because of the financial services offered by their banks that have been deemed to be outdated by the clients. In our century, the march of technology, internet connectivity, and digital connectivity toward financial institutions are inevitable. This economic down- 
turn leads financial institutions to turn to technology in order to improve their services vis-a-vis the clients, and prevent the spread of this trust crisis. In many financial service organizations, technology has moved from the back offices to the front. The industry has become the world's most digitized one according to Strategy \& Analysis; they say that 60 percent of all retail banking transactions now are done online. In Europe, more than 47 percent of ultra-high-net-worth individuals use Facebook and more than 40 percent of high-net-worth individuals under the age of 50 view social media as an important channel for communicating with their bank, according to a recent study by Assetinum. Similarly, a recent Deutsche Bank study finds that more than 33 percent of all new banking business with customers between the ages of 16 and 39 is conducted fully on the Web. Among these younger clients, online channels (including social media) have become one of the most important information sources for investment decisions.

Before 2005, the West African financial system was underdeveloped and the banking system was concentrated in two or three commercial banks in the majority of the WAEMU countries. Financing entrepreneurial activities and housing remain a challenge. Banque Centrale des Etats de l'Afrique de l'Ouest (BCEAO) is a unique central bank for the eight countries and governs the financial institutions across the WAEMU1. Currently the financial system in West Africa is dominated by the banking sector it is evolving rapidly with the emergence of new transactional banking groups and microfinances. This evolution in the banking system is still not enough to be named among the best financial regions in the world. A TIPCEE working paper ${ }^{2}$ is stating that the actual interest rates charged are ranged between $31 \%$ and $36 \%$. The report explains that interest rates charged by banks for loans are the result of persistently high bank operating costs and a risky lending environment. Additional work is needed to lower operating costs and technology may have an important role to play in helping all financial institutions in West Africa become more efficient. Many authors have discussed bout Fintech and its innovation in banking and financial services [1] [2]. In particular regarding West African, the question that needs to be addressed is: how will the Fintech revolution aid in the development of the West African financial sector? This paper intended to examine the West African financial system, assess his situation from 2005-2014 and show the opportunity that could be taken by using Fintech in their financial system. The rest of the paper is structured as follows: in the second section there will be a look into the literature reviewing Fintech and its revolution. The third section will explore the West African financial sector and section four will explain the way of digitization settlement and the Fintech market segments. Then in section five will show the opportunity for the West African financial market, followed by the conclusion.

\section{Literature Review}

Fintech is the term coined to describe the intersection between finance and technology. It may refer to technical innovation being applied in a traditional financial service con${ }^{1}$ West African Economy Monetary Union.

${ }^{2}$ Quotes the Daily Graphic published on January 25, 2005. 
text, or it may refer to innovative financial service offerings which disrupt the existing financial services market. It is one of the most exciting and dynamic segments of the financial services market. The IT authors argued that Fintech is conceptually defined as a new type of financial service based on IT company's broad types of user, which is combined with IT technology and other financial services like remittance, asset management, payment and so on [3]. His development such as electronic, digital and Fintech service has an increasing advancement in service productivity, which addresses the expectations of the consumers. Moreover, it's challenging and caters to the attitudes of consumers who are accepting of new technology products to gain market opportunities.

Fintech refers to new solutions which demonstrate an incremental or radical disruptive innovation development of applications, processes, products or business models in the financial services industry [4]. According to the managing partner and founder of arbor venture, Fintech innovation is an important component of economic development, especially for emerging economies [5]. Looking at the development of Fintech in the world and its impact of Fintech solutions in Africa, it is important to notice that in more than fifteen African markets, there are now more mobile money accounts than bank accounts. Therefore, Fintech in developing countries is not only about making existing services more convenient, it is creating new infrastructure and providing for greater inclusion of millions of people in the real economy [6]. "People need banking, but they don't necessarily need banks", said the chief client experience, digital, and marketing officer during interconnect 2015. Despite the advantages of the Fintech innovations, some customers in the world are still skeptics [7]. A significant share of private banking clients, especially in Europe, still prefer to delegate their wealth management needs to a traditional advisor or private bank with an established track record, instead of seeking their investment advice online. However, clients in Asia and the U.S. are increasingly willing to make some investment decisions themselves and even to share ideas online through social media platforms the impact of Fintech on the banking industry may lead to the disaggregation of the value chain interfaces may come about that help bundle the product offerings of specialized providers, thereby becoming a substitute for an integrated provider [8]. The distribution related economies that were eluded to, may actually lead to such disaggregation of the value chain. Fintech innovations are still catching up with financial regulators. Therefore, there is a higher risk of loss for lenders if strict due diligence procedures are not consistently followed as with regulated financial institutions [9].

\section{Financial Sector in West Africa}

\subsection{West Africa Overview}

Historically, West Africa has experienced major migratory trends. Dating back to before the Colonial Period, the region has long been considered as a trading center for goods and services. One resilient manifestation has been commercial migration in which traders migrate across borders to participate in commercial activities. This phenomenon is informed by an understanding of West Africa as an economic unit. More- 
over, while migration in pre-colonial and colonial times was defined by trade routes, modern intraregional migration is determined and shaped by: post-colonial national boundaries the forces of the global economy (cross border migrant trade, structural adjustment, human trafficking, civil strife (Liberia, Côte d'Ivoire)), territorial definitions of sovereignty, regional integration (ECOWAS), and an ongoing view of West Africa as a single economic unit. From a geographic standpoint, it is difficult to clearly define which migratory routes people have followed. There is no rule of thumb saying, for example, that French-speaking societies are more integrated amongst themselves in migratory terms. Looking at places of origin and destination may help only partially.

Four major destinations in the region have been Nigeria, Ghana, Senegal and Côte d'Ivoire. However more recently, Nigeria and Ghana experienced both inbound and outbound movement. In the $1960 \mathrm{~s}$, Ghana was host to Nigerians, but by the $1970 \mathrm{~s}$ tables turned with thousands of Ghanaians looking for work in prosperous Nigeria. Currently, people move back and forth, to and from both countries. People from Burkina Faso, Liberia, Mali, Niger and Togo have also been on the move to other locations within West Africa. The view of West Africa as a geo-political unit was confirmed by many of those interviewed during this project, whether in the private or public sector, migrants or traders. People responded to the notion of West Africans rather than migrants. In fact, the ECOWAS regime has tried to ensure that its rules reflect that premise. Article 27 of the ECOWAS charter speaks of common citizenship acquired by nationals of member states, which as of 1979 has allowed people from member states to move throughout the region without needing a visa and stay in another member state for up to 90 days. By 1986 and again in 1992, member countries affirmed the right of member nationals to reside and work in other ECOWAS countries, with the stipulation that they needed to register. This latter move is perceived as a means to keep control of the foreign born population. In addition to a fluid notion of migration, statistical data is largely unavailable, thus making it difficult to know with certainty how many West Africans reside in other member countries of ECOWAS. For example, Ghana's immigration office estimates that $15 \%$ of its population is West African. Similarly, it is estimated that $10 \%$ of the Nigerian population are migrants from Africa, West and Central Africa predominantly.

\subsection{Banking Sector}

The WAEMU financial sector has grown in the last decade. Since the beginning of the 2000's, bank credit has increased substantially in most countries (Figure 1). This trend continued in 2012 taking the ratio to GDP to about 20 percent, from 14 percent in 2010 (with an average credit growth rate of 6 percent annually). The number of bank branches and bank accounts also increased significantly in recent years. Credit is largely short-term and goes mostly to manufacturing and the service sector (particularly trade, hotels, and restaurants). Clients vary substantially across banks, with some dealing mostly with bigger firms (including subsidiaries of multinationals in the case of foreign-owned banks) and others are more focused on domestic retail clients. In some 


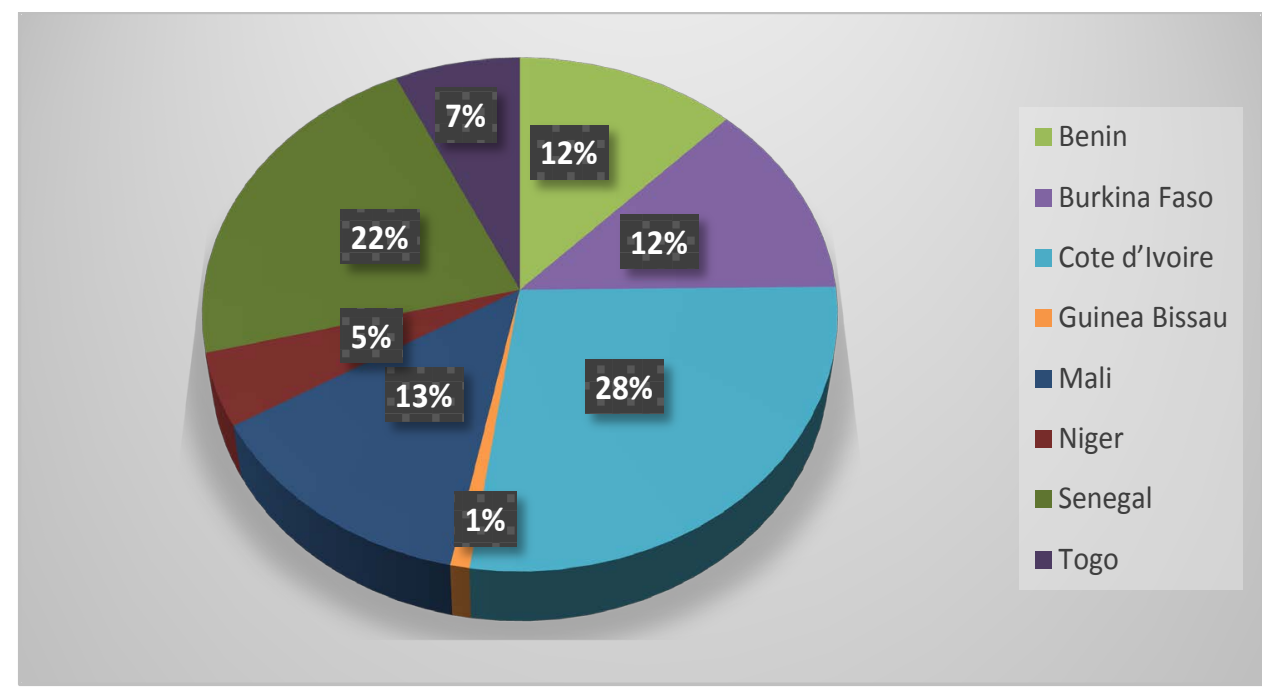

Figure 1. Distribution of bank assets by country, 2011.

countries, increased competition from micro finances and new business strategies from entrants have led to diversification of the traditional customer base of the bank and higher competition [10]. Most banks are significantly exposed to government securities and more generally to the public sectors. An important recent development has been the emergence in the WAEMU of cross-border (Pan-African) banking groups. This has often occurred through the purchase of domestic banks, in particular by Moroccan and Nigerian groups seeking to expand out of their home markets. More than twenty big groups, accounting for most of the banking system, are involved in cross-border activities within the WAEMU (Figure 2).

The largest market in terms of assets is Cote d'Ivoire and Senegal comes in as second largest.

These groups, which are mostly incorporated as subsidiaries, are funded through local deposits. This funding model, coupled with their domestic orientation, explains why the direct impact of the global crisis was rather mild on these banks. European banks have remained engaged in the region, whereas Pan-African banking groups have taken the opportunity to expand at this juncture. However, banking in the WAEMU is still conducted within national borders. Cross-border flow to households or corporations within the region are largely in the form of syndicated loans involving a sister bank located in the country of the client; in the recent period, Côte d'Ivoire and Senegal were net recipients of these flows, whereas most other countries were net exporters. The flows are still relatively small, at about 1.6 percent of total lending in 2012 [11]. Limited integration is also attested by large differences in lending and deposit rates for households and enterprises across countries. Limited banking integration reflects a number of factors, such as the still limited economic integration, but also the importance of local knowledge for lending activities. The main cross-border financial flows in the WAEMU involve bank purchases of government paper (The main lending flows are leading by Ivory Coast and Senegal, but they remain small). 


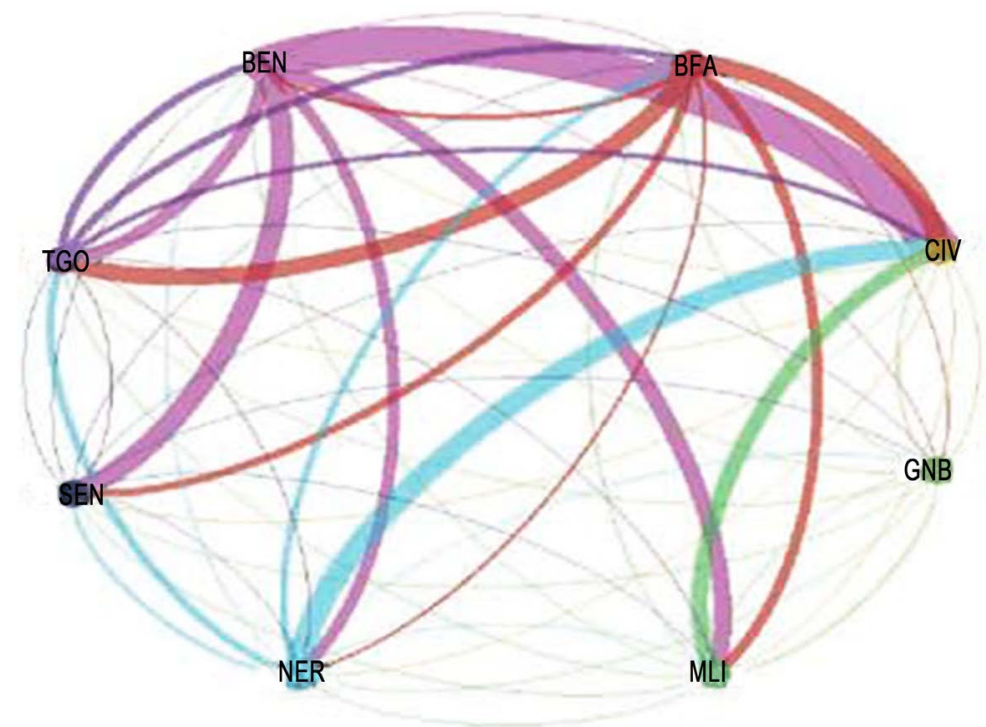

Figure 2. Intra-regional net lending, 2011 [12].

On average, the banking system is liquid and well capitalized, although the situation varies substantially across banks and countries (Figure 2 and Table 1). As mentioned earlier, banks are very heterogeneous with regard to business models, size, geographical coverage, profitability, and vulnerabilities. Aggregate information hides this diversity and therefore needs to be complemented by a more granular approach.

The analysis of financial soundness indicators (which are highly aggregated, available with long lags, and backward-looking; Table 2) confirm the need for a dual approach. Both lending concentrations, which are high in all countries of the union and quality of assets (Figure 3), as reflected in high gross nonperforming loans (Figure 4), represent the main risks. Lack of data regrettably did not allow assessing risks related to the exposure of banks to WAEMU sovereigns, but this exposure is clearly increasing, raising new (possibly systemic) risks ${ }^{3}$. The broader exposure of banks to the public sectors (e.g., through public enterprises) is even more substantial. The emergence of crossborder banking groups also brings new risks; for instance, cross-border banks may propagate foreign stock into the domestic economy. Another potential risk arises when large banking groups have similar portfolios making them susceptible to similar stock in this case, although the diversification of the banking portfolio reduces the probability of an idiosyncratic failure, it increases the probability of a systemic crisis. Some of these banking groups are large enough to be considered domestic systemically important financial institutions.

Compliance with prudential norms remains low for a number of ratios. As shown in Figure 1, compliance varies across countries and across ratios. Also, there are banks in all countries breaching the capital adequacy ratio (lack of granular data did not permit scaling the compliance of prudential ratio by bank's assets). Compliance improved in late 2012, but this reflected changes made to two ratios (the transformation ratio, which ${ }^{3}$ Imam and Koleras, 2013 (the Senegal pilot study exposed to sovereign risk). 
Table 1. Main banking groups in the WAEMU (source: banking commission of WAEMU).

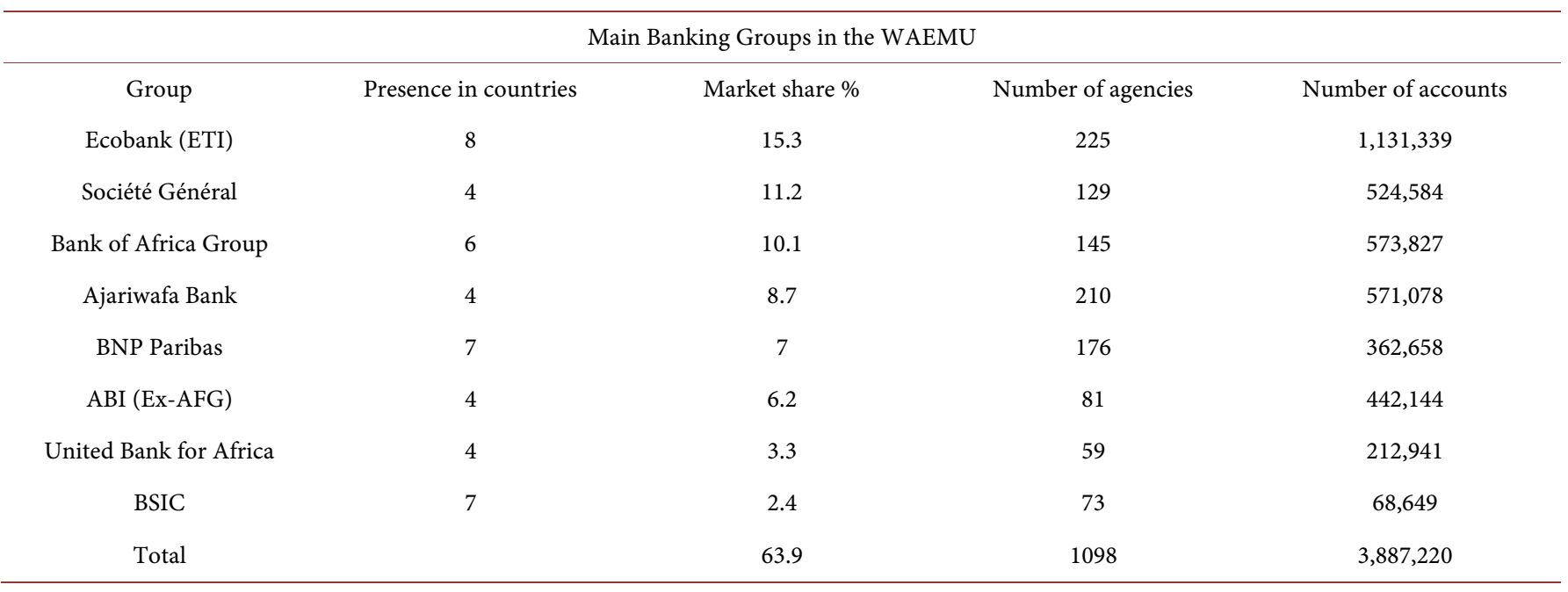

Table 2. WAEMU: Financial soundness indicators 2005-2014.

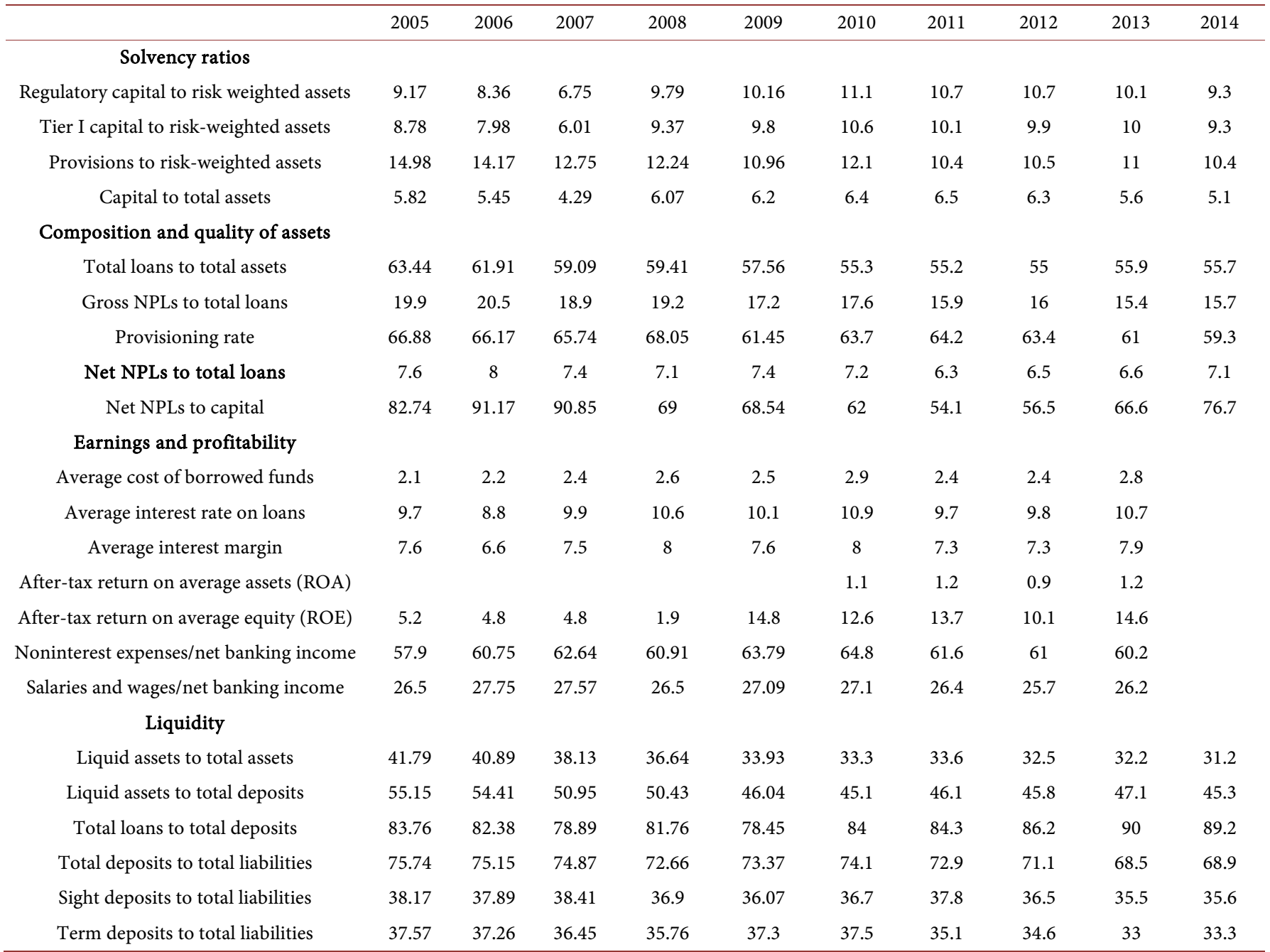

Source: Central Bank of West African States, IMF, African Department database, and Regional Economic Outlook database. 


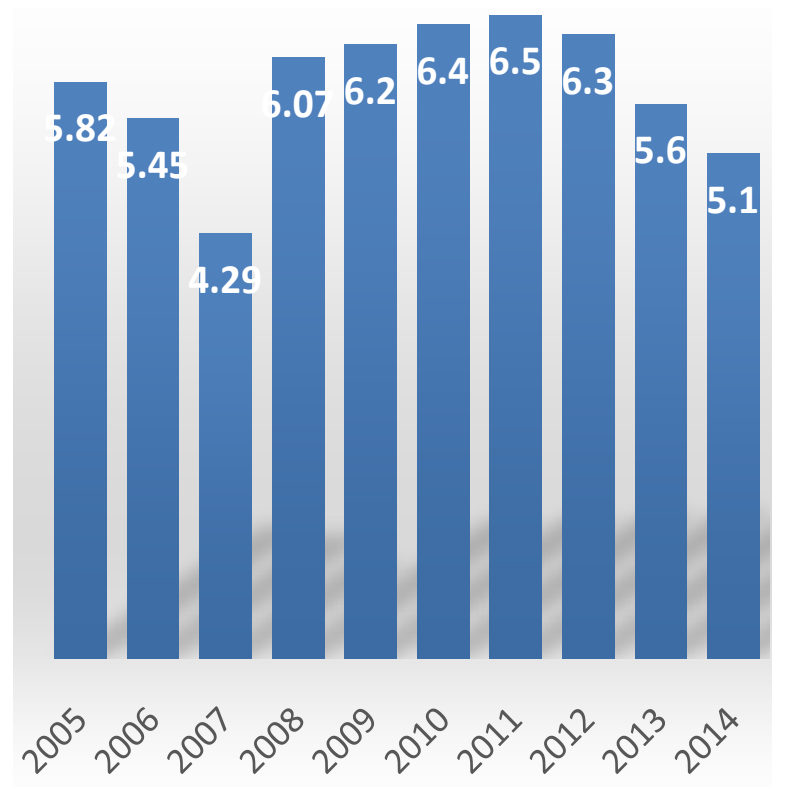

Figure 3. Solvency ratios: capital to total assets.

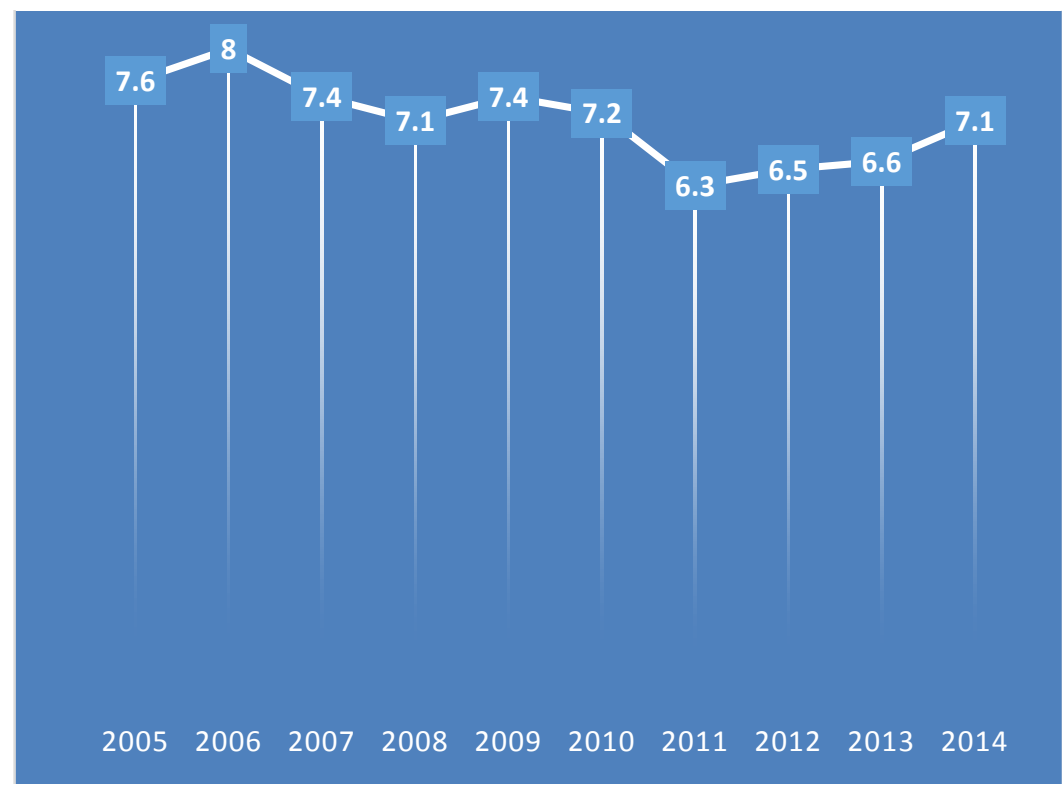

Figure 4. Net NPLs to total loans.

was lowered from 75 to 50 percent, and the ratio on portfolio structure, which was abolished). Progress over the last few years has been limited, which suggests a degree of regulatory forbearance. In addition, some of these norms are not in line with international standards. Low compliance is particularly problematic for ratios that are less demanding than international standards, such as the one on risk division (see ahead). As discussed in the last section, there are other important issues to address with regard to the supervision of regional groups and the crisis prevention and resolution frameworks [13]. 


\section{Digitization Settlement and the Fintech Market Segments}

To settle digitization in the financial services of a region, country or area, the management team or the decision makers should begin with the following instructions: Firstly, determine the expectations about digitization held by internal stakeholders in the different companies per country, such as the board of directors. However, if the company is publicly traded, then the expectations of the shareholders have to be determined. Secondly, assess the digitization expectations of current and potential future clients. Lastly, assess the threat of disruption to their current business from more digitally proficient competitors, including those outside the traditional financial-services industry.

It is also important to understand how evolving technology will continue to drive digitization in the industry then decide whether to focus on the external front-office (client-facing) or middle and back-office (internal) implications of digitization or both. After considering these issues, decision makers or senior executives can begin to define their institutional approach to digitization.

The market segments where Fintech are most active are [14].

\subsection{Data and Analytics}

Financial sector creates a massive amount of data exploiting by Fintech companies. They use this data to segment customer populations, identify opportunities for new products and services and optimize pricing. Also, the data can be used to manage the risks (fraud, cybersecurity breach, etc.). Confidentiality of sensitive personal data being the top priority of regulators and customers, Fintech works with this personal data with a particular consideration.

\subsection{Artificial Intelligence}

In this segment, products may use data and analytics to computerize the decision making processes. Technology that may be typically valuable when the speed of the information and/or volume of the information mean that real-time human analysis is unattainable. For example, Amazon uses artificial intelligence working in recommendation engines (buying purchase recommendations).

\subsection{Payments}

Innovative start-ups, retailers, established banks, card companies and other payment services providers are the Payment systems that underpin the services that enable funds to be transferred between people and institutions. They are all seeking to offer new payment solutions to meet consumer demand for payment instruments that are more secure, efficient and convenient.

\subsection{Digital currencies}

Different to traditional currencies, digital or crypto currencies are generated across peer to peer $(\mathrm{P} 2 \mathrm{P})$ computer networks. They are also used to monitor and verify the transfer of currency. 


\subsection{Crowd Funding}

Crowd funding is the practice of raising many small amounts of money (funding) from a large number of people (crowd), typically via the internet or social media. Fintech is still working in this market segment to preserve stability and consumer protection.

\section{Opportunity for the West African Financial Sector}

\subsection{Enhancing the Value Proposition and Driving Sales}

Fintech firms are recognizing that many of their clients are online, spending a lot of time in social communities and networks. Embracing the industry axiom, "Be where your clients are", banks have to develop mobile applications and leverage new technologies more innovatively to establish closer ties to clients, especially the digital natives. Designed correctly, such apps will help them identify client needs earlier and with greater precision. They will also provide online channels for transactions, advice, and information exchange, as well as client-to-client networking. As a result, firms will be better able to develop new offerings for their current customers' base and attract new clients. Studies show that customers frequently request innovative and interactive customer financial education tools, and better-educated clients show significantly higher levels of investment activity. For example, a survey in Germany by Deutsche Bank concluded that educated customers typically hold equities in their investment portfolios at rates two to three times higher than less educated clients do.

Current industry examples show that a good balance between pull-information and push-communication and sales effectiveness is critical in these efforts. For example, providing clients with customized, relevant information and research about developments in the markets can be an opportunity to open a dialogue and assess their current needs. Several U.S. Fintech firms have designed innovative apps that have become hugely popular in a very short time. Besides providing news and the latest research reports, these apps allow clients to view their account balances and investment positions in a convenient and hassle-free way and handle basic transactions on their own.

For example, banks can use their platforms to connect clients through interactive communities based on shared interests via social media such as Twitter or Facebook.

\subsection{Reducing Operating Costs}

Fintech firms should leverage technology to drive standardization, efficiency, and automation. Banks can use digitization internally to streamline processes, such as more efficiently rolling out new programs and investment ideas to their relationship managers

Digitization can also allow banks to make account information available for clients to access themselves, at their own convenience, rather than calling and asking a relationship manager to fax something to them.

Another element of cost reduction is the better use of relationship managers and specialists time. For example, they can use online chats and videoconferences to provide more content in client interactions, thereby drastically reducing unproductive time. 


\subsection{Easier Access to Loans}

For many consumers, such as millennials and small business owners still getting established, Fintech can provide access to funds previously unobtainable to them. Due to the fact that non-traditional forms of determining creditworthiness are used, often in conjunction with credit reports, lenders can get a comprehensive financial footprint of a borrower that goes beyond credit history. As a result, Fintech is seen by many as being more balanced and fair in terms of making loan decisions.

\subsection{Lower Interest Rates}

Because lenders through Fintech companies typically have access to a more comprehensive profile of borrowers, they can offer lower interest rates for loans compared to traditional financial institutions. Having more comprehensive information about the applicant helps manage risk as lenders can more accurately determine the probability that someone will repay their loan.

\section{Conclusions}

Fintech represents a significant change for the financial sector industry. Its market segment such as data analytics, artificial intelligence, payments, digital currencies, crowd funding, will enhance financial system in its relationship with the customers. West Africa is a greenfield opportunity for Fintech. Mobile payments have revolutionized the financial industry in West Africa (orange money in Cote d'Ivoire), where more than two thirds of people have a cellphone, but only around one-third have bank accounts. In Sub Saharan Africa, some countries like South Africa are among the fastest growing Fintech markets in the world.

In Africa, over $50 \%$ of the population are living in areas without roads, electricity, security, infrastructure and not reachable by branch banking, but most of the people own a mobile phone. The Fintech revolution can reach these people and change the current status quo of the financial services industry in West Africa.

This study is limited by the access of the original documentation made by the Economic Community of West African States (ECOWAS) due to the political instability. Indeed, the political instability between 2011 and 2013 in West Africa has slowed the expansion of the financial services industry and makes the acquisition of the data dependent upon the World Bank and other organizations complicated.

\section{References}

[1] Alt, R., Beck, R. and Smits, M. Fin Tech and the Transformation of the Financial Industry. http://static.springer.com/sgw/documents/1572269/application/pdf/12525_CfP_FinTech+0 7+cmi.pdf

[2] Boot, A.W.A. (2016) Understanding the Future of Banking Scale \& Scope Economies, and Fintech. Chapter 25, 1-3. http://www.arnoudboot.nl/files/files/Boot\%202016\%20-\%20Understanding\%20the\%20Futu re\%20of\%20Banking_\%20Scale\%20and\%20Scope\%20Economies\%20and\%20Fintech.pdf

[3] Lee, T.-H. and Kim, H.-W. (2015) An Exploratory Study on Fintech Industry in Korea: 
Crowdfunding Case. http://iieng.org/images/proceedings_pdf/7333E0815045.pdf

[4] Puschmann, T. (2012) The Rise of Customer-Oriented Banking-Electronic Markets Are Paving the Way for Change in the Financial Industry. Electronics Markets, 22, 203-215.

https://www.researchgate.net/publication/233936387 http://dx.doi.org/10.1007/s12525-012-0106-2

[5] Guzy, M. (2016) Fintech Book. Wiley, Chichester, West Sussex.

[6] bKash (2014) Fintech Book. Wiley, Chichester, West Sussex. https://books.google.ci/books?id=uTEWswEACAAJ\&pg=PR6\&hl=fr\&source=gbs_selected pages \&cad $=2 \# \mathrm{v}=$ onepage $\& \mathrm{q} \& \mathrm{f}=$ false

[7] Lenzhofer, A., Reber, C., Diemers, D. and Kramer, S. (2013) Taking Wealth Management Digital. http://www.strategyand.pwc.com/reports/taking-wealth-management-digital

[8] Boot, A.W.A. (2016) Understanding the Future of Banking: Scale \& Scopes Economics and Fintech. Chapter 25, 4-5.

http://www.arnoudboot.nl/files/files/Boot\%202016\%20-\%20Understanding\%20the\%20Futu re\%20of\%20Banking_\%20Scale\%20and\%20Scope\%20Economies\%20and\%20Fintech.pdf

[9] Kjergaard, D. The Pros and Cons of the Alternative Funding, Vol. 24, Issue 3. https://ithinkbigger.com/pros-cons-alternative-funding/

[10] Pennacchi, G. (2012) Narrow Banking. Annual Review of Financial Economics. https://business.illinois.edu/gpennacc/GPNarrowBankARFE.pdf

[11] International Monetary Fund (2013) Modifications to the Current List of Financial Soundness Indicators. Background Paper.

https://www.imf.org/external/np/pp/eng/2013/111313.pdf

[12] The West African Economy and Monetary Union WAEMU (UEMOA). http://www.housingfinanceafrica.org/wp-content/uploads/2012/10/WAEMU.pdf

[13] Favara, G. (2009) An Empirical Reassessment of the Relationship between Finance and Growth. https://www.imf.org/external/pubs/ft/wp/2003/wp03123.pdf

[14] Chishti, S. and Barberis, J. (2016) The Fintech Book. Wiley, Chichester, West Sussex.

Submit or recommend next manuscript to SCIRP and we will provide best service for you:

Accepting pre-submission inquiries through Email, Facebook, LinkedIn, Twitter, etc. A wide selection of journals (inclusive of 9 subjects, more than 200 journals)

Providing 24-hour high-quality service

User-friendly online submission system

Fair and swift peer-review system

Efficient typesetting and proofreading procedure

Display of the result of downloads and visits, as well as the number of cited articles

Maximum dissemination of your research work

Submit your manuscript at: http://papersubmission.scirp.org/

Or contact ojapps@scirp.org 